\title{
The Institutional and Cultural Logics of Legal Commensuration: Blood Money and Negotiated Justice in China ${ }^{1}$
}

\author{
Kwai Hang Ng \\ University of California, San Diego
}

$\mathrm{Xin} \mathrm{He}$

City University of Hong Kong

Legal commensuration is a complex mechanism of valuation. It entails social exchanges among parties in the litigational context. The way the law evaluates the unevaluable is guided by many specific facts about the parties and is influenced by its own institutional priorities. The criminal reconciliation process in China is used as a real-world empirical illustration. Drawing mainly on data collected from fieldwork investigation of two basic-level courts, this article identifies two factors that affect the process and outcome of legal commensuration: institutional interests promoting reconciliation and the cultural meanings of money. Political considerations play a decisive role in incentivizing judges to facilitate reconciliation. But the cultural meanings of money also shape judicial outcomes. In particular, blood money is valued both for its certainty and its symbolic value as a token of apology. Through a brief comparison of the Chinese and U.S. courts, the article shows that our emphasis on process can generate a more socially grounded understanding of legal commensuration.

\section{INTRODUCTION}

Recent studies have identified commensuration as a key mechanism that defines and generates values in things that are otherwise discrete and

${ }^{1}$ The authors would like to thank Isaac Martin and Yang Su for comments on earlier versions of the article. Xin He presented an earlier version of the article at the University of

(C) 2017 by The University of Chicago. All rights reserved. 0002-9602/2017/12204-0003\$10.00 
unique (e.g., Cohen 1984; Porter 1995; Espeland and Stevens 1998; Levin and Espeland 2002; Espeland and Vannebo 2007; Karpik 2010; Fourcade 2011). Simply put, commensuration is the process of turning qualities into quantities or the process of transforming "different qualities into a common metric" (Espeland and Stevens 1998, p. 314). Its sweeping power comes from its ability to transpose different entities into numerical equivalents, creating a structure for comparing uncertain and unique qualities. In everyday life, commensuration takes different guises, from accountancy (the calculation of a company or a person's "net worth"; see Carruthers and Espeland 1991), to cost-benefit analysis (for a comparative historical overview, see Porter [1995]; see also Espeland and Vannebo [2007]), to census tracking (the creation of categories such as "Hispanics," "unemployed"; see Anderson 1990), to ranking (U.S. News and World Report college rankings, Michelin Guide's five-star ranking; see Espeland and Sauder 2007); these exercises share a logic of analysis that at root presupposes that different phenomena are comparable and measurable.

The law ranks among the most fascinating institutions for studying how "invaluable" and "priceless" things are compensated for and thereby monetized. Legal commensuration, arguably the most prevalent form of institutionalized commensuration, has systematically monetized what would otherwise be known as "singular" life experiences of different kinds (Zelizer $1979,1985)$. It allows for an economistic coordination of qualitatively different feelings and emotions: money is adopted as the purportedly unified medium for the calculation of lives lost and damaged, the pain and suffering caused by injury, and the grief experienced by the loss of loved ones.

Legal commensuration is marked by the broad range it covers in pulling different qualities together for comparison. The long arm of the law takes commensuration to newer frontiers to price the priceless (Ackerman and Heinzerling 2004), valuating things as varied as a healthy environment (Anderson and Leal [1991] 2001; Ackerman and Heinzerling 2002), carbon emissions (Levin and Espeland 2002), oil spills (Fourcade 2011), and children's health (Lutter 2000).

Yet, despite the adoption of a language that seems elaborated and precise, legal commensuration remains at root a varied exercise. As some legal scholars vividly suggest, the law "has flip-flopped like a captured mackerel, with

British Columbia Law School (April 2015) and thanks the participants for their comments. The research reported here was supported by the National Science Foundation (grant no. 1252067). Xin He acknowledges a grant from the Research Grants Council of the Hong Kong Special Administrative Region, China (project no. CityU 11403114). Special thanks to the Chinese judges who helped arrange our fieldwork investigations and those who kindly accepted our interviews. We are also grateful for the comments of the AJS reviewers. Direct correspondence to Kwai Hang Ng, Department of Sociology, University of California, San Diego California 92093. E-mail: kwng@ucsd.edu 
about as much coherence" (Bell and O'Connell 1997, p. 43). Victims and their dependents are compensated dissimilarly in similar cases. From a jurisprudential perspective, such variability is often attributed to the different types of damages that the law allows. Economic damages provide commensuration for "pecuniary losses" such as medical costs and lost salaries that can be calculated relatively straightforwardly. But noneconomic damages provide commensuration for other intangible things-loss of companionship, sexual consortium, emotional support, among others. And punitive damages implicitly legitimize the commensuration of outrage (Sunstein, Kahneman, and Schkade 2000). ${ }^{2}$ Posner and Sunstein (2005, p. 539) identify the expansive scope of legal commensuration that makes it complex: it makes damages a function of lost income, it uses case-specific numbers to assess damages, it focuses on the pain and suffering felt by the deceased (in case of death), and it takes into consideration the economic and emotional loss to dependents. The law works to achieve many things at once-compensating victims, sanctioning wrongdoers, and upholding its own moral legitimacy. So understood, legal commensuration monetizes feelings and experiences that are difficult, and perhaps inappropriate, to check out like items at the cash register. ${ }^{3}$

This paper takes a different tack to explaining the variability of legal commensuration by turning to the process of legal commensuration. Why is legal commensuration complex and inevitably varied? Our argument is that it has much to do with the relational nature of the monetary exchange between parties in litigation. To look into such relational quality, we study the practice of legal commensuration. Legal commensuration is complex not just because many different intangible feelings and experiences are converted into money. This is the legal explanation. In practice, legal commensuration is varied and complex because it is an act of sociation between the

\footnotetext{
${ }^{2}$ In civil law countries such as Germany, damages are strictly limited to reparation and compensation (German Civil Code [Buergerliches Gesetzbuch, 1900]). American tort law allows money to be used for both compensatory and punitive purposes, blurring the line between civil damages and criminal punishment. For that reason, punitive damages are opposed by some legal commentators, fearing that the award of "outrage" damages undermines the rationality of American tort law. Worries of unpredictability have fueled recurrent calls for even more rules and control mechanisms (Sunstein et al. 2000). But for others, punitive damages remain a powerful legal expression of moral indignation (Vidmar and Wolfe 2009).

${ }^{3}$ This tendency to provide commensuration is certainly not without its critics. Richard Abel, writing from the perspective of critical legal studies, remarks, "Damages commodify a unique experience, injury, by substituting the universal equivalent, money, as when a plaintiff's attorney asks the jury to assign a monetary value to each second of the victim's pain and then aggregate it over a lifetime of suffering" (Abel 1990, p. 804). He adds, "Damages for pain and suffering extrapolate Bentham's hedonic calculus to its logically absurd conclusion, insisting that every pain suffered can be offset by an equivalent pleasure, which can be bought for money" (p. 803).
} 
party who pays and the party who receives. It is a practice that turns on the material interests and cultural values of litigants and judges as well as on the institutional context under which disparate experiences are evaluated.

The relational character of legal commensuration is illustrated by an empirical examination of criminal reconciliation in China. Officially known as criminal reconciliation, or 刑事和解 ( $x$ ing shi he jie) in Chinese, the practice allows some defendants to substitute money for jail time. Its use defies the popular perception of the system as a draconian and repressive one that still relies on stiff punishment to achieve deterrence. On the surface, criminal reconciliation is a highly "transactional" process that epitomizes the role of money as a form of cure-all compensation. China has adopted, largely by borrowing from the laws governing civil litigations in the United States and Europe, a body of technical rules to provide commensuration for losses and damages of different qualities into a common metric. A young person's life lost in the urban, more developed part of the country is valued at around 400,000 yuan today. The price would be 200,000 yuan if the same life were lost in the less economically developed inland part of China. The effect of criminal reconciliation is that it uses money to offset what is supposedly "just" punishment. As a critic points out bluntly, "If you have money, you will get a lenient sentence; if you are poor, you will go to prison" (Li 2006, p. 96). Of course, offering money to compensate crimes is neither a new nor a uniquely Chinese phenomenon. In The Philosophy of Money, Georg Simmel famously discusses the utilitarian nature of wergild, or man payment, in Anglo-Saxon England ([1907] 1990, pp. 355-9). But the practice is so prevalent that it has become an integral part of the Chinese criminal justice system. The practice fits well with China party-state's new policy of 宽严相济(kuan yan xiang ji), or “balancing leniency and severity," to temper the widespread use of harsh punishment (Trevaskes 2009, 2010). In 2012, the Chinese government decided to "recognize" it during its latest revision of the Criminal Procedure Law (CPL 2012). The new law stipulates that "criminal reconciliation" can be carried out in public prosecution cases. ${ }^{4}$

As will be shown, the process of criminal reconciliation by no means entails a simple application of legal rules. We identify two sets of factors cru-

\footnotetext{
${ }^{4}$ Chinese scholars have commented extensively on this practice, with focuses primarily on the legal and policy repercussions of the practice. Many of them investigate the extent to which criminal reconciliation is practiced at different levels of China's court system (Ge 2008; Song 2008, 2011; Sun 2011; Chen 2011; Sha 2012). Studies on the practice written in English are also beginning to appear. Among the very first was Trevaskes (2009), who looked at the practice and policy behind it, particularly in relation to the procuratorate's new leniency agenda. Other more recent studies that examine the practice include Zheng (2012), Mok and Wong (2013), Xiang (2013), and Rosenzweig et al. (2012). Many of these studies analyze criminal reconciliation from a legalistic perspective and the legislative development with regard to this practice. Their discussions consider the legal theories justifying this form of reconciliatory procedure in the criminal justice system.
} 
cial for understanding the process and outcome of commensuration: the institutional priorities guiding judges' decisions and the cultural norms governing the relationship between economic compensation and justice. Studying reconciliation in China allows us to examine moments under which the search for commensuration reveals judges' subjectivity and social skills. Chinese judges are well aware of their designated priority to maintain social stability. In fact, they are almost entirely transparent about the social reasons justifying their discretionary use of power. How money is moralistically valued in the Chinese social and cultural context means that litigants' subjectivity also plays an important part in the process of reconciliation. Some victims agree to take money as atonement from offenders; others do not. The variety of responses reveals how the complex processes of criminal reconciliation must also take litigants' subjectivity into consideration.

The specifics about the institutional and cultural concerns embedded in the Chinese case of criminal reconciliation may be unique to China, but they underline the relational quality that connects parties through monetary exchange, a quality that distinguishes legal commensuration from other forms of commensuration. In the final part of this article, we briefly compare our studied case of China with the practice of criminal reconciliation in the United States to see how money is valued and used in a different institutional context.

\section{MONEY COMMENSURATION IN LAW}

It is no exaggeration to say that the classical sociological critique of money comes from a somewhat one-sided reading of Simmel. Money, as mentioned, is considered "the most terrible destroyer of form." Simmel writes in The Philosophy of Money, "The more the life of society becomes dominated by monetary relationships, the more the relativistic character of existence finds its expression in conscious life" ([1907] 1990, p. 512). Since value finds a representation in money, which is only expressed quantitatively, so the argument goes, money serves as the common metric that homogenizes qualities into quantities. What is overlooked is that, for Simmel, money is also a form of sociation in itself, and as such, constituted by social relations. In a move that echoes Durkheim's argument about individualism as a new form of solidarity ([1898] 2013), Simmel suggests that the use of money requires "social-psychological quasi-religious faith" ([1907] 1990, p. 245). For this reason money, for Simmel, is also a social institution (Ingham 2004, pp. 63-66). Recent works in the sociology of money literature further question the accuracy of treating money as a neutral, universal medium for economic exchanges. Zelizer $(1979,1985,1994)$ shows that people actually differentiate money according to type and social setting. Other studies show that the value of money varies across social contexts and social transactions. 
For example, immoral practices such as crime, theft, and corruption produce "dirty" or "bitter" money (Shipton 1989). In Islamic societies, money generated from riba or interest on loans is sinful because it violates the Koran's prohibition on usury. Zelizer (1994, pp. 36-70) documents a variety of domestic earmarking practices that commonly occurred in American households and shows how these were articulated in conjunction with evolving gender roles and policy imperatives. Heath and Soll (1996) show how consumers undertake mental budgeting that labels the different types and sources of money that come into and flow out of their households (cf. Thaler 1999). Gerriets (1985) finds that money in Christian Ireland was more valued because it helped fulfill social obligations and elevated one's social status. Different interpretations of money are by no means limited to personal and household practices. Both private and public organizations earmark their internal and external budgets to meet their needs and obligations (Stinchcombe 2001).

All of these examples suggest that the differences in types of money come from the fact that varied social meanings are attached to the sources and recipients of money. In practice, there are alternative evaluation modes that often conflict and compete with the abstract mechanism of evaluation to which the market economy subscribes. People and institutions categorize and distinguish money. These monetary practices reflect a variety of social, psychological, political, and organizational imperatives. As a result, the commensurability of money is complicated by social and organizational considerations (Carruthers 2010).

The tension between money as a medium of quantification and as an expression of symbolic qualities is particularly visible in legal commensuration. On the one hand, money is the "currency" offered to rationally make up a person's utility that is harmed by someone else's wrongdoing. Yet the meaning of money is deeply affected by the circumstances under which it is offered. Despite the purported "impersonal" nature of money, the questions of who pays and who gets to be paid loom large in legal commensuration. Legal scholar Tom Baker (2001), in his study of the practices of collecting tort compensation in the United States, refers to "blood money," or money offered by offenders from their own pockets, as a type of money fraught with moral meanings. Baker distinguishes it from insurance money. As Baker (2001, p. 276) puts it, "[blood money] hurts defendants in a way that money paid on behalf of a defendant by a liability insurance company cannot." The concept of blood money suggests that claims about what is or is not commensurable are as much about the loss that is compared to money as about the social character of the money. The social source of money makes a difference even in a formal legal process. Not all money can buy love and sympathy, but some money can, under some circumstances. Beyond its practical valence, there is a clear moral valence that the term "blood 
money" tries to capture. The social history about how and by whom money is raised is integral to the consideration, at least from the victims' perspective, of whether money can be accepted as a fair compensation.

Only a few sociolegal studies have explained how law valuates in practice. Zelizer (1985), based on her analysis of published law reports, traces the shifting cultural norms that have pushed the law to provide commensuration for the emotional and sentimental value of children lost through wrongful death. In explaining the difference in the practice of monetizing death between tort laws and administrative regulations, Posner and Sunstein (2005) cite different considerations of the two institutional regimes: the former emphasizes compensation, while the latter stresses deterrence. Based on her comparative study of oil spills litigation, Fourcade (2011) outlines a theory of valuation to explain how French and U.S. laws assign different economic values to nature. Numerous factors are at play, but it is the cultural and institutional acceptability of money that most fundamentally shapes the scope of economic valuation in a given society.

Yet while scholars refer to the social nature of legal commensuration in some of the existing works, they tend to ignore the process that brings commensuration into being. Questions regarding the practices of legal and social institutions in facilitating commensuration are overlooked or deflected in these accounts. While scholars see law as a social product, they still take the fixity of legal rules and categories too much for granted. As a result, the literature is quite silent on the question of how different parties (judges, lawyers, litigants) use the law at times to compete, at times to cooperate, and at times to achieve commensuration.

This article studies the situated judgments that generate legal commensuration. We take serious the idea that law is practiced. We explore how commensurability is constructed by the actors involved in the legal process. Litigants and judges see legal rules not so much as rigid rules and mandates but as a symbolic resource to contest, to negotiate, and to relate with one another (Edelman et al. 1992; Stryker 1990).

Specifically, we see legal commensuration as an institutionalized form of sociation. As such, it is a process that is deeply influenced by institutional interests of the court and the broader cultural values of a society. How valuation is done in the legal setting in practice is as much determined by the values and interests of disputants as by the motivations and resources of judges. Through studying the dynamics of the decision-making process and the interactions between litigation parties and courts, we bring institutional and cultural logics to bear on the theoretical conception of legal commensuration.

Institutional constraints inform the priorities and concerns of judges in allowing the use of money in exchange for punitive sanctions. The institutional concern of judges, be it the delivery of justice and the offering of 
make-whole compensation in liberal democratic societies, or central policy implementation and the maintenance of social stability in authoritarian regimes, inevitably looms large in the decision-making process (Posner 2008). Throughout the process, the law is used as a fluid set of guidelines for judges to sanction litigants' requests for offering or receiving compensation.

Cultural beliefs and values also play a crucial role in the process. Cultural perception of the use of money defines the legitimate scope of commensuration. It defines the circumstances under which money is considered an acceptable ersatz. As we will show with our empirical case of China, the commensuration process takes into account social "intangibles" such as defendants' life circumstances, the apologetic quality of the money offered, and the effort invested in raising the money. Furthermore, judges, litigants, and their lawyers are involved in constructing ideas of fairness that resonate with broader cultural values and norms.

\section{STUDYING CRIMINAL RECONCILIATION IN TWO CHINESE COURTS}

The study is based on an ethnographic study of criminal reconciliation at two basic-level courts: Court X in China's northwestern hinterland and Court $\mathrm{Y}$ in the southern coastal region.

The county in which Court $\mathrm{X}$ is located has been economically left behind since the economic reform that began in the 1980s. The regional economy grew during the initial stage of the reform period but has stagnated since the 1990s: by 2012, the GDP per capita had reached only around 5,200 yuan (National Bureau of Statistics in China 2013). Agriculture has been the pillar industry because of the fertile valleys formed by the Yellow River and a climate congenial to the growing of wheat. The policy separating income and expenses, in Chinese 收支两条线 (shou zhi liang tiao xian), one of the most important policies affecting the financial relationship between the courts and local government, has never been enforced in the case of Court X. The cash-strapped local government offers limited financial support to the court. As a result, the operating expenses of the court come largely and directly from the litigation fees and fines that it imposes on criminal defendants.

In contrast, the county in which Court $\mathrm{Y}$ is located has a population of about half a million. It was, for a long time, the agricultural hinterland of nearby urbanized and more economically developed cities. Rice cultivation and aquaculture (breeding of freshwater fish, shellfish, mussels, and clams) remain the main activities of its strong agricultural industry. But the county itself has also undergone urbanization and industrialization. Its investment-

\footnotetext{
${ }^{5}$ For an evolution of this policy, which has had huge impacts on judicial behaviors, see Zhu (2011).
} 
friendly economic policy has attracted foreign and domestic companies to set up factories there. Young migrant workers have streamed into the county, seeking employment in the county's booming industrial complexes and in the local construction companies that are building many of these new manufacturing and assembling facilities. The meeting of the locals and the migrants, their rural versus urban background, and their differences in life experiences have brought a steady increase in social tensions and clashes. The booming economy in coastal China also means that Court $\mathrm{Y}$ received more generous subsidies for its daily operation from the local government than its rural counterpart did. Balancing the budget is less of a concern for the administrators of the court.

As part of our larger study of the Chinese legal system, one of us visited Court X twice, in 2011 and 2012. Each visit lasted for about a month. We conducted extensive interviews with five judges in the criminal courts. We focused on the process of criminal reconciliation and discussed individual cases with the judges (see below).

We first visited Court Y in 2012 for a month to establish a relationship with the judges working there. One year later, we returned to spend another month with the same group of judges. We asked for and were granted permission to sit in on the criminal courts. We surveyed the docket and picked out cases that we believed were most likely to involve criminal reconciliation. We attended about 30 trials, of which about a third mentioned reconciliation as an option that both sides agreed to pursue. It was clear to us, however, that reconciliation often began before the trial and continued afterwards.

To obtain an in-depth look into the process of criminal reconciliation, we conducted lengthy interviews with four to five judges in each of the two courts that have experiences with criminal reconciliation in Courts $\mathrm{X}$ and $\mathrm{Y}$. We also interviewed the president of Court $\mathrm{Y}$ to get the perspective of an administrator. The interviews averaged 60-90 minutes in length. Some lasted more than two hours. We made an effort to talk to some of the judges multiple times. We started an interview by asking judges to describe the criminal reconciliation process to us. We then moved to deeper questions such as some of the successful and failed cases they had presided over as well as the stories behind the compensation offered in those cases. We paid special attention to the understandings that different defendants and victims brought to the idea of economic compensation and the incentives of the judges in coordinating it.

The interviews provide us a rich source of qualitative data on criminal reconciliation as a cultural and political practice. We also obtained from Court Y a full list of written judgments from cases that involved the use of criminal reconciliation in 2012. These written opinions are invaluable for studying the effects of monetary compensation on sentencing in China. 
We derived from the judgments an overview of the main categories of cases that were reconciled and the social and demographic characteristics of the defendants who offered monetary compensation to plaintiffs. Overall, the analysis of written judgments shows us how courts react to defendants' efforts to offer compensation to plaintiffs. ${ }^{6}$

There are some practices shared by Court X and Court Y in carrying out criminal reconciliation. We use data and materials from both courts to present our analysis. There is, however, an important distinction in their attitude towards criminal fines. Comparing Courts $\mathrm{X}$ and $\mathrm{Y}$ brings out the differences in the reactions of well-off and poor courts to the offering of criminal fines.

\section{WHY IS IT COMMON TO COLLECT BLOOD MONEY?}

Although not officially recognized until recently, reconciliation has permeated China's criminal justice system since the early 1990s. Through private negotiations among parties, offenders can have their sentences reduced or even suspended, by offering economic compensation to their victims in exchange for forgiveness. In some regions, almost half of the minor injury cases filed at the police office were reconciled and thereby dropped (Ge 2008, p. 340; cf. Huang 2013), and about a third of the criminal cases in courts were reconciled (Cheng 2012). By most scholarly accounts, minor physical assaults and traffic-related crimes are the two main types of crimes in which criminal reconciliation is practiced. Reconciliation, however, is also used in cases of fraud, theft, and crimes related to "disruption of public order." Criminal reconciliation is used more selectively and restrictively in cases of violent crime such as murder, where there might be bargaining for life imprisonment rather than the death penalty.

As the term "criminal reconciliation" suggests, the victim and the defendant come together in order to reconcile, often with the court or the procuratorate as mediator. From the defendant's perspective, the purpose of reconciling is to obtain forgiveness from the victim or the family, which is now a formally recognized mitigation factor under the new Criminal Procedure Law. For the victim, reconciliation is an opportunity to obtain financial compensation from the defendant. In an important sense, the transaction of reconciliation resembles a formal contract. The hallmark of this Chinese-style reconciliation is direct payment from the defendant's pocket to the victim's. As mentioned, this is a form of blood money. The process of reconciliation of course must receive the blessing of the court, as the power

${ }^{6}$ We triangulate our findings with judges working in the criminal courts of provinces and cities including Jiangsu, Guangdong, Guangxi, Guizhou, Yunnan, Beijing, and Tianjin. Our discussions also incorporate what we learned from judges outside of Court $\mathrm{X}$ and Court Y. 
of sentencing is in the judge's hands. If the defendant agrees to pay and the victim agrees to forgive, then the judge will execute "the contract" by sentencing the defendant leniently or in many cases, suspending the sentence.

Table 1 depicts the total number of defendants who arrived at a criminal reconciliation agreement with their victims in Court Y in 2012. In total, 116 defendants reconciled with their victims, accounting for about $20 \%$ of all criminal cases decided by Court $\mathrm{Y}$ in that year. ${ }^{7}$ Broadly, we categorize the reconciled cases into four categories - minor violent crimes, traffic-related crimes, property crimes, and public order crimes.

Minor violent crimes make up the largest category among cases that were reconciled that year. Of the 46 defendants within this category, 42 were convicted of "intentionally inflicting bodily harm upon another," the Chinese equivalent of battery in its criminal law.

The second most common type of case in Court Y is traffic-related crime. As in the United States, death and serious injury claims are more likely to prompt a demand for money in China, even in the absence of obvious intentional wrongdoing (Baker 2001, p. 299). Yet, while there is a general reluctance to collect blood money in the United States and the act is considered an exception rather than the norm, collecting blood money is a common practice in China. Why is there no stigma attached to it?

The answer lies in the unique legal circumstances under which blood money is collected in China. Unlike in the United States where insurance money is generally available in tort litigations, insurance money is still relatively rare or offered at rates much lower than the rates that the courts in China would use to calculate damages.

Take traffic-related crime cases as an example. The laws require licensed motor vehicle drivers to buy "transportation insurance." A policy that meets the legal minimum requirement pays up to around 130,000 yuan (about $\$ 21,300$ ) to a victim injured or killed. In China, this amount is not enough to cover the full "value" of a lost life in accordance with legal rules and regulations (which ranges from 200,000 to 500,000 yuan, depending on the local economy) and the expenses of prolonged medical care and lost income due to injury. The disparity is even larger when there is more than one victim.

More important perhaps is the fact that any discussion of insurance money is often moot. A substantial majority of traffic-related crime cases involve motorcycles or electrical bicycles. Many of these vehicles are unregistered and the drivers uninsured and often unlicensed. In the county where Court Y is, the government has banned motorcycles within the city. Yet, as any visitors to the county and to many other cities could attest, motorcycles zig-

\footnotetext{
${ }^{7}$ We do not have statistics from Court X, but judging from what we learned from individual judges, the two most common types of reconciled cases in Court $\mathrm{X}$ were minor violent crime and traffic-related crime.
} 
The Institutional and Cultural Logics of Legal Commensuration

TABLE 1

Criminal Cases Reconciled at Court Y in 2012

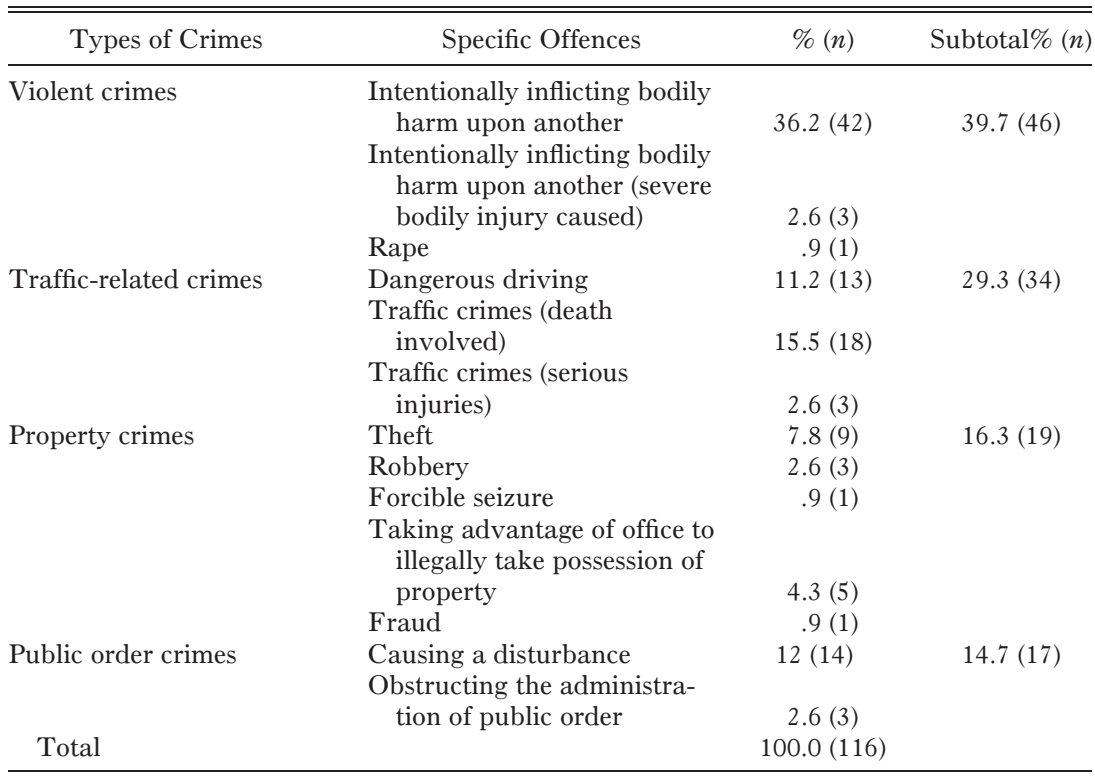

zagging between cars and sometimes pedestrians are a daily sight. Rapid economic development means that most cities lack the infrastructure and high-capacity public transport system to cope with fast-growing traffic demand. In this situation, motorcycles are a cheap, convenient, but risky means of transportation for low-income laborers. Local governments often turn a blind eye to these unregistered motorcycles.

Furthermore, enforcement of judgments is a chronic problem in China. In theory, victims can obtain compensation through a collateral civil proceeding to criminal procedure. They may even receive judgments that purportedly instruct defendants to pay them in accordance with the compensatory rules on the books. But many of these paper judgments cannot be enforced in China's still fragile civil litigation system (Clarke 1996; He 2009; Song 2009). One judge said, "Even those litigants without much legal knowledge know that enforcing a civil judgment is difficult. Pursuing judgment money requires a lot of effort. A victim often ends up not being able to collect the money stated in a judgment. But we will tell the victim-if you reach an agreement with the defendant, you can get the money immediately. You don't have to forgive if you don't get the money."

${ }^{8}$ All statements from judges and litigants were translated by the authors unless otherwise noted. 
In the United States, the demand for blood money is avoided because there are easier targets, including liability insurance money, or in some cases, a plaintiff's own underinsured motorists coverage (Baker 2001, p. 293). In China, blood money is preferred because blood money is the easier target in the absence of a comprehensive insurance system. Blood money in this context means safe money for victims and their families. For cases that have reached the trial stage, this is the last opportunity for victims to obtain economic compensation with certainty. When a victim's family agrees to forgive, the defendant or his or her family pays. In fact, a victim's family would not extend forgiveness unless they had received the money. The certainty of blood money is most appealing to victims and defendants. Once both sides have agreed to reconciliation, the presiding judge will deliver a light or a suspended sentence to reflect the degree of forgiveness offered by the victim or his family. Court judgments are very precise on whether and how much a defendant has paid. They are also specific about how much is still owed to the victim and when the defendant will pay off the balance. Official judgments therefore double as a "contractual agreement" for the reconciled parties. For example, in the following judgment on a case in which a tow truck driver killed a truck driver who had stopped on the freeway to examine a flat tire, the judge sets the outstanding sum to be paid by the defendant to the victim's family: "In the course of this trial, defendant X voluntarily agreed to compensate Y (victim)'s family a total of 20,000 yuan. He has already paid 15,000 yuan to the family. He received the forgiveness from the family of the victim."

\section{WHY DO JUDGES FAVOR CRIMINAL RECONCILIATION?}

Although there is a growing identification with the ideology of professional independence (Balme 2010), Chinese judges still see themselves primarily as government bureaucrats. Courts in China do not have, to quote the famous phrase of political scientist Davis Easton, "a reservoir of favorable attitudes or good will that helps members to accept or tolerate outputs to which they are opposed or the effects of which they see as damaging to their wants" (1965, p. 273). Judges, as officials of a weak state bureaucracy, know that their limited power can be more effectively used for coordinating than for judging. From this perspective, a winner-takes-all adjudicative decision runs the risk of challenges by the losing party. Chinese judges are eager to dissociate themselves from situations where they have to commit to decisions that may be reversed on appeal. Contrary to common perception, China's judicial system has become more populist (He 2009; Trevaskes 2010; Liebman 2012). Criminal reconciliation, as part of the bigger trend of the civilianization of criminal offenses, is an act of self-preservation. Judges 
dread having their judgments appealed or petitioned. The Chinese justice system is not value driven, as reflected in the minimal role of its constitution in shaping legal development. It is policy driven. Social stability is the paramount policy concern of the Chinese communist regime and by extension its justice system. As bureaucrats, judges see their primary goal as the preservation of social stability. In fact, the number of petitions and appeals against judgments handed down by individual courts has become a crucial indicator of courts' job performance (Minzner 2009). Judges fear being "done in" by persistent litigants. This fear has been exacerbated in recent years with the party-state's agenda of maintaining stability. Reconciliation is appeal proof; by definition it already has gotten the agreement of the litigating parties. "Honestly, we prefer reconciliation in many cases because this gives us the best protection," a judge admitted. From their perspective, a done deal is as good as a closed case. "If a victim makes a petition, I'm the one who's responsible. If they accept to take money from the defendant, it is the best outcome for me," the judge added.

Besides the potential threat of petitions from disgruntled litigants, reconciliation gives the judiciary some leeway to resolve the case in its own way without defying the authority of its stronger sister bureaucracies of the police and the procuratorate. Some judges said they were sometimes uncomfortable convicting in cases that had flimsy evidence provided by the police and the prosecutor. China's state bureaucracies coexist in a highly complex system of interdependency and competition (Lampton 1992). Open disagreement among state bureaucracies is avoided at all costs. Criminal reconciliation helps judges avoid defying the recommendation of the procuratorate by suspending sentences for defendants who reconcile with victims. A judge we interviewed recalled the difficulty of adjudicating one privately initiated criminal case (as opposed to those initiated by the procuratorate) of personal injury and property loss arising from a fight between two middle-aged women. The judge said the police provided only a brief five-page report. The plaintiff requested 800 yuan for medical expenses for her injury and 14,000 yuan for an earring lost during a fight in the defendant's furniture shop. The plaintiff also insisted that the defendant be sentenced to jail. According to the defendant's version, the plaintiff harassed her and had taken her computer and two chairs from her shop. The judge was dissatisfied with the evidence. Did the plaintiff actually wear the earring on the day of the fight? Was the earring really lost during the fight? Why did the fight start? Who started it? How was the injury to the plaintiff inflicted? While the laws stipulate that the court may return cases to the procuratorate or the police for further investigation, gathering fresh evidence late in the trial stage was considered impractical by most Chinese judges. Reconciliation was in practice the best option for the presiding judge. 
American Journal of Sociology

\section{THE ROLE OF THE JUDGES}

This section examines the role of judicial officials in the process of criminal reconciliation. Judges are the facilitators of reconciliation. We observed some of the judges at work in criminal trials. They were businesslike and professional. They did not appear to be particularly warm or congenial, but they projected qualities often found among bureaucrats: detachment, efficiency, and unflappability. They harnessed their institutional and judicial power to present scenarios for litigants that made reconciliation appear to be the optimal, if not the only, solution. At the same time, they use the soft power of moral suasion to influence litigants. A few cases demonstrate the rich and sophisticated diversity of strategies used by Chinese judges. We illustrate not only cases that were quickly reconciled but also hard cases that ended without a reconciliation agreement and those that were reconciled only after protracted and difficult negotiations. Hard cases are particularly instructive; they show that despite their knowledge and skills, judges can do only so much to facilitate reconciliation. The defendant's ability to pay and, more important, the victim's willingness to forgive are out of judges' control. The process of legal bargaining in China has both similarities to and differences from that in the United States. Baker states that in the United States, "Bargaining for blood money turns more on commonsense morality and practicality" (2001, p. 276). In China, judges play a pivotal role, sometimes in the shadow of law but other times out of the reach of law. Of course, U.S. judges, as Baker points out, participate in the bargaining process to facilitate settlement. For example, they may pressure institutional litigants (such as workers' compensation carriers) to pay more to individuals to get a settlement. By and large, however, they play a secondary role to counsel for plaintiffs and defendants (Baker 2001, p. 308). By comparison, Chinese judges intervene more. Besides appealing to the law, Chinese judges often fall back on cultural notions of remorse, repentance, or just simply good attitude to persuade litigants. The net result is that criminal reconciliation in China becomes an eclectic procedure that is partly pragmatic and calculating but partly moralistic and evaluative.

\section{No Deal}

It takes money to facilitate forgiveness. The instrumental nature of criminal reconciliation cannot be ignored. When a defendant has no or little money to offer to his victim, efforts to reconcile are unlikely to bear fruit. In the absence of forgiveness from the victim, a judge sometimes returns the maximum or near-maximum sentence to a convicted defendant. In Court X, one judge recounted a case in which eight passengers on a tractor were killed when it was hit by a tourist bus on a rainy day. The bus driver who was found partially responsible was sentenced to seven years. Even 
though the tractor's driver (who was also killed) had a role in the accident, the fact that the bus driver could not offer any money to the families of the dead loomed large in the judge's sentencing decision. The presiding judge said, "I rarely gave someone the maximum sentence. But in that case, the driver was very poor; he had a dilapidated house in a remote mountainous area. So was the owner of the bus: the guy bought the bus just a few days before the accident with money borrowed from his friends. The seven-year sentence was indeed not enough. The widows and the mothers of the boys killed were crying in my office."

The threat of being put behind bars gives great leverage to judges to pressure defendants to participate in criminal reconciliation. Victims and their families will not offer forgiveness without compensation. If they think a sentence is too light, they may even appeal or make petitions to the court and other government units. This is the scenario that judges and their courts most fear.

In one case, the defendant, an unlicensed motorcyclist, struck an elderly woman on the county's main road on a winter morning when it was still dark. The motorcyclist was initially knocked unconscious. When he regained consciousness, the man did not move the woman from the road. He was seen fleeing the scene. The injured woman was then run over by a bus; the bus driver was not held culpable because he had not seen her in the dark road. The motorcyclist later explained that he had been scared and disoriented and wanted medical treatment.

One point of contention was whether the woman's death was caused by the impact of the motorcycle or being crushed by the bus. Chinese criminal law punishes someone who flees after causing injury in a traffic accident but makes a distinction between fleeing and fleeing causing death. If the victim was killed by the collision with the motorcycle, the motorist would have to be charged with fleeing after an accident, which mandated imprisonment for three to seven years. However, if the victim survived the first accident, then her death was caused by the motorcyclist fleeing the scene and leaving her in the road. In that case, the defendant could be charged with fleeing causing another person's death, which would bring imprisonment of not less than seven years (the heaviest sentence for a traffic-related crime). The prosecutor from the People's Procuratorate asked the judge to sentence the defendant for the crime of "fleeing after causing an accident," because the procuratorate considered the status of the victim after the first accident inconclusive. The prosecutor did not file a charge of fleeing causing death.

This trial took place in Court Y during our fieldwork. What would otherwise have been a routine trial turned emotionally intense when the son of the deceased asked to speak before the court. Criminal trials in China are dominated by judges and prosecutors. Other people rarely speak. But the victim's son, a man in his mid-40s, delivered the most emotional speech that 
we had heard in Court Y. Sitting beside the public prosecutor, he spoke loudly while staring at the panel of judges and the defendant: "Can't you understand middle school-level Chinese? The coroner's report clearly suggests that it is this man who caused my mother's death. I do not understand why the law is so lenient. My mom was still alive. It was his fleeing that caused her death!" The man said the prosecutor's recommendation ignored the evidence presented in the coroner's report, which, according to him, indicated that the fatal spinal damage had been caused by the second accident, not the first one.

Right after the trial had concluded, we talked to the son. He was still visibly angry. Had the defendant offered his family any blood money, would he still have asked the judge to convict the defendant for the more serious crime? The man replied that he still would have wanted the more serious charge. "It has nothing to do with the money. It is about justice. I can't understand why they decided not to go for the more serious charge."

We did not have access to the coroner's report. In our interview, the presiding judge said the investigation report contained an important piece of information that the prosecutor had not mentioned. A pedestrian who had seen the accident stated that the bus ran over the woman almost at the same time that the man regained consciousness, implying that there had been no time for him to get her out of the road, and therefore his running away had no role in the woman's death. The judge told us that although she would not convict the defendant for causing death by fleeing, she would not let him off with a light sentence either. Within the sentencing range mandated by the law, she had the leeway to sentence the defendant to as little as three years and to as many as seven. The judge frankly admitted that she had to take the feelings of the victim's son into consideration. The defendant was a migrant worker, and he did not offer much blood money to the son. In fact, the victim's son was also a migrant worker; his mother had come to visit him, and on the day of the accident she had been carrying a big basket of vegetables and meat on her way back from the morning market to prepare meals for her son's family.

"Until the day of the trial, all the defendant offered was covering the funeral costs of 16,000 yuan," the judge explained. "And this was only done after three rounds of mediation. The victim's son was very unhappy." She continued, "There is an expectation that defendants in this kind of trafficrelated crime would cover funeral costs. That's the least they are supposed to do. Often that's still not enough, but defendants are expected to do so. A life lost in our county, assuming that the defendant is found responsible, can easily translate into a judgment awarding a compensation of 400,000 yuan."

The judge shrugged off the notion that the son did not care about money. Otherwise he would not have negotiated with the defendant in the first place, she said. Nonetheless, the judge acknowledged that in this type of 
traffic-related case, the attitude of the victim's family holds sway. "If the victim's family doesn't change their attitude, it is likely that we'll have to levy a heavier punishment within the range," she said.

\section{Deal}

Judges play a crucial enabling role in cases that are reconciled. It is rare for a victim and a defendant in a criminal case to reconcile on their own. Residual hatred and emotions linger. As judges in Courts $\mathrm{X}$ and $\mathrm{Y}$ told us, in personal assault cases, or in traffic-related cases causing serious injury or even death, most defendants wanted to avoid their victims. One judge explained, "Some feel guilty to see the victim. Some fear that they'll be yelled at or even beaten up by the victim's family members and friends. Some people just want to avoid the whole thing. To offer a personal apology to the one you hurt is easier said than done."

From our fieldwork, we noticed that presiding judges often act as gobetweens among defendants and victims during the process of reconciliation. When asked how they promote reconciliation, the judges we interviewed stressed the value of separate face-to-face meetings with both sides, sometimes multiple times, before any discussion of a definite proposal of reconciliation. What judges do in criminal reconciliation is not that far removed from what they do in civil mediation. They broker agreements by caucusing and meeting with the two sides separately. They hear the demands of both sides. They facilitate negotiation by framing what one side says to the other in the best possible light, usually by accentuating what one party is willing to concede while downplaying any remaining disagreements (Waye and Xiong 2011; Ng and He 2014).

Judges often present themselves as offering impartial analyses to defendants and victims. Of course judges are not disinterested third parties. They most want to avoid petition or appeal. Getting both sides to agree to reconcile is a surefire way for judges to protect themselves. Yet they spin the "what if" narrative as a form of objective analysis to litigants, much as U.S. judges can when facilitating plea bargains. "We'll tell litigant X, if there's no reconciliation, according to the law, I will send you to jail for $\mathrm{x}$ years. We also tell litigant $\mathrm{Y}$, don't expect to get any money from the defendant if he goes to jail. He's not going to pay," a judge in Court Y said.

Judicial officials are also known to lecture parties on their "legal responsibilities," even though such responsibilities are in fact conventional moral views. A case documented by Su (2000) illustrates how judges pressure both the defendant and the victim in order to facilitate criminal reconciliation. The case revolved around an extramarital affair. The husband $\mathrm{H}$ whose wife had had an affair with another man demanded a compensation of 10,000 yuan from the other man. But the other man, his neighbor N, was 
only willing to pay 7,000 yuan. The judge said to the husband, who threatened N's young children,

I understand your feelings and the reasons for your excessive behavior. ... You have been emotionally assaulted and your reputation damaged. . . . N should give you some compensation, but the whole discussion has gone awry. Think it over. You can't ask for too much or act unreasonably. In this situation, RMB10,000 is high. Think about it carefully and remember that your wife was also in the wrong. Now that $\mathrm{N}$ has brought the matter to this court, you should not bother him anymore. If you act excessively again, the law will punish you.

Meanwhile, another judge from the same court said to N, "You shouldn't blame the other side. ... You started the whole thing. It is on your shoulders because you broke the law. You have severely affected another person's family and the couple's emotional relationship, and you've hurt society. You should look at your behavior from the point of view of breaking the law, look at the results - the responsibility is yours and that makes your illegal behavior even more serious" (Upham 2005, p. 1691; Upham's translation).

The pressure was clearly felt by both sides. As a result, the parties settled on 8,000 yuan. As Su (2000) points out, there was no legal basis for the payment at all. In other cases where the judge has a clear mandate of the law, she will use it as a tool to convince litigants to agree to reconcile. In the case in which the plaintiff insisted on both criminal and civil charges for the injury suffered in the defendant's furniture shop, the judge first said to the defendant, "This might involve up to three years of imprisonment." A few minutes later, when the defendant was asked to leave the courtroom, the judge said to the plaintiff and her legal representative, "Fighting is usually mutual. How can you claim that the responsibilities are all borne by the other party in a fight occurring in her shop? How can you prove you really wore the earrings that day? Why did you wear such expensive earrings when you knew your disputes might be escalated into fighting? And you have taken away a computer and two chairs." The plaintiff, after talking privately to her attorney, immediately proposed dropping the criminal charges and asked for only 3,000 yuan, which the defendant quickly agreed to pay.

Once a deal is reached, the court will ask the victim's family to write a letter of forgiveness. In some cases, a victim only agrees to partly forgive; that means the victim would not insist on maximum sentence and might even agree to a light sentence but would oppose suspending the entire sentence. It is common for a judge to inform the victim that "lighter sentencing" includes the possibility of suspended sentence and see if there would be an objection. The judge sees to it that both sides agree on the content of the reconciliation agreement. The practice protects her from any future appeals or 
petitions: the victim's side cannot accept the money and then complain about the lesser punishment given out by the court.

\section{From No Deal to Deal}

There are cases in which reconciliation at first seemed impossible but a deal was eventually struck after the extra efforts put in by courts. In high-profile cases with broad political repercussions, sometimes the entire judiciary will rally to push through an agreement. These tough cases can be found throughout the court system. The following case was recounted by a Supreme People's Court judge who worked in the Death Penalty Confirmation Division during an interview we conducted for another project:

At the beginning, the judge was asked to persuade the victim's family to reconcile (in order to get the side to agree to a suspended death sentence). When it didn't work, the chief judge was asked to do work. When it didn't work, the vice division head was asked to do work. Finally, the division head was sent to talk to the family too. These people were all senior judicial officials. But they were instructed to visit the victim's family again and again. They were sometimes humiliated by the victim's family. The victim's side made claims that these judges had taken bribes because they worked so hard to facilitate a deal. It was crazy!

The Supreme People's Court is the apex of the Chinese court hierarchy. We heard similar stories from the frontline judges we interviewed in Court X. One judge there shared the following story. A 13-year-old girl died as a result of medical malpractice in an unlicensed community clinic. The owner of the clinic, a "barefoot" doctor (someone who had received minimal medical training), failed to conduct a required skin test before administering an injection. The girl died because of an allergic reaction to the drug. No reconciliation could be reached during the trial. The defendant had neither personal savings nor property. The court sentenced the doctor to 14 years in prison and instructed him to pay damages of 220,000 yuan to the girl's family. Since the doctor had no money and was already in jail, the young girl's family did not receive a penny. Like most petitioners in China, the bereaved father's initial efforts appeared futile. Most petitioners would have given up after a while. But the death of his daughter turned this father into a fierce and persistent petitioner - the type of no-holds-barred petitioner that Chinese judges fear most. On the eve of the first anniversary of his daughter's death, the man leapt into Gold Water River, right in front of Tiananmen Square in Beijing. His dramatic act drew the attention of senior Chinese officials. Court X was soon instructed to "do some work."

The problem for Court X was that the judgment had already been handed down. The defendant was in jail and had no incentive or means to pay. The 
case needed to be reopened. And there was still the problem of money, or the lack thereof, which had led to the failure to reconcile in the original trial. The court had an annual budget of about 300,000 yuan for special remedies. Our judge recalled that many other desperate petitioners were also fighting for special remedies. The court eventually learned that the doctor's mother, who was in her late 60s, had some savings. The judge then tried everything he could to persuade the doctor's mother to provide some compensation. He first informed the intermediate-level court, the prison authority, and the procuratorate, of the situation. He then promised that if the doctor's mother could pay 80,000 yuan, which was all her savings, the court would add 20,000 to make the total compensation 100,000 yuan. The case would be retried, and the doctor's imprisonment could be reduced to 10 years to take the forgiveness of the victim's family (if given) into account.

As soon as the doctor's mother agreed to pay, the judge persuaded the girl's family to accept the offer. "Although 100,000 was less than half of what was awarded in the original judgment, this was all the court could do." It took almost another year before the victim's father agreed to the reconciliation agreement. During that period, the court showered the bereaved father with goodwill. For example, the court provided him with lunch each time he visited the court. When the judge responsible for enforcing the judgment visited the jailed doctor to ask him to persuade his mother to compensate the victim's family, he took the victim's father with him, so that the two men could get to know each other. The enforcement judge would drop off the man at home after each prison visit. The girl's father was convinced that the court had exhausted all possible means to resolve his case. He was touched by these efforts and by the fact that most of the money would come from the convicted doctor's aged mother. He agreed to end his campaign and signed off on the reconciliation agreement that the court brokered.

Although much less than what was originally awarded, the 100,000 yuan was valued higher than its face value. The court's willingness to accommodate and the judges' kind gestures were "added" components of the compensation. It is a scenario where political constraints forced the court to "personalize" compensation. The efforts added value to the money used to compensate for the pain suffered by the man.

\section{BLOOD MONEY AND COMMENSURATION}

We have shown the institutional interests that lead courts to facilitate the translation of criminal offenses to cash. Another dimension of legal commensuration revolves around the role of culture in shaping values in legal compensation. Litigants, and even judges, elicit noneconomic value for a process that is supposedly operated on a uniform matrix of money. Blood money is valued more because of the hardship experienced by defendants 
and their families in raising it. In many cases, even though the money offered still falls short of the nominal sum of money in a paper verdict, a victim would accept blood money as the sign of a sincere apology. Song (2009) concludes that defendants in all successful cases of criminal reconciliation without exception made apologies to victims or their relatives. "The offering of blood money must be performed as part of an act of sincere apology," said a judge in Court Y. "Just offering money is not enough. If a defendant doesn't show a sincere attitude, some victim's families will reject the offer." The same judge went on to describe one of the cases she had heard:

The defendant already paid 60,000 yuan to the victim's family [the victim was killed]. But the victims were still very angry. As it turned out, defendant's family was not very apologetic. They were not most willing to pay [but they paid anyway] and they showed it to the victim's family. They didn't visit the victim's family.

So I explained to both sides and asked them to get together. I urged two sides to put their emotions aside. I told the victim's family that if this defendant [a 20-something young man] was sent to jail, you wouldn't get any money from his family. And I asked the defendant's family if they were willing to pay more and to apologize. They agreed. Sometimes, once that initial hurdle is overcome, people then show a lot of emotions. I've seen defendants and their families kowtow to victim's family to express remorse in meetings.

The defendant's family in this case eventually agreed to offer 100,000 yuan, on top of the 60,000 yuan already paid. In return, the victim's family agreed to forgive. Reviewing the judgments of Court Y showed that judges often commented on the defendants' attitude. This was especially important in assault and battery cases, in which victims were often angered by the violence inflicted on them. In one case where a victim was beaten up by two defendants and their friends in a bar, the defendants, according to the judge, "actively sought to compensate the economic loss suffered by the victim" (they offered a total of 35,000 yuan to the victim). The judge suspended a one-year sentence for two defendants in return.

Cynics may say that the delivery of an apology is mere posturing and that it is money that really matters. This view, although tempting in view of the calculative nature of the process, is too simplistic. Money matters, of course. Yet people tend to value blood money differently in view of the hardship a defendant or his family went through in order to raise the money. In the judgments of Court $\mathrm{Y}$, some defendants were commended by the court for trying to raise money to compensate their victims. In one case, a 22-yearold man was accused of causing the death of his friend, a passenger on his unregistered motorcycle. The young man was a construction worker with very little income. In the judgment, the judge underlined the fact that his family had worked hard to pay the victim's family 71,500 yuan despite their own economic hardship. 


\section{American Journal of Sociology}

The value of blood money is affected by the social nexus wherein reconciliation deals are worked out. In general, we can typify different kinds of blood money by the source from which blood money is drawn as well as the nature of the recipient.

\section{Sources}

Money that comes from personal investment hurts the least, since the taking of this type of blood money would not cripple defendants to pay for essentials such as food and housing. There is now an emerging middle class in China. Middle-class families have money invested in bank savings accounts or stocks. This is why critics of criminal reconciliation describe the policy as one that promotes inequality between rich and poor. Blood money from rich people who have savings does not hurt as much. We should point out, however, that defendants involved in traffic-related crimes are more often poor migrant workers. In Court Y, a clear majority of the litigants that we surveyed did not seem to come from a middle- or upper-middle-class background. Table 2 shows a breakdown by education of the defendants in criminal reconciliation in Court Y in 2012-13. Almost half of the defendants received education only up to junior high, while another $30 \%$ received just elementary education or no education. Using education as a proxy for defendants' socioeconomic status, the data from Court Y suggest that most of the defendants come from a working-class background.

The second type of "blood money" is money borrowed from family members and friends. This type of blood money hurts more than spare money does. As mentioned, very few defendants have personal savings. In those cases, the defendant's entire family digs deep into their personal relationship networks (guanxi) to help the defendant avoid prison. This puts the defendant and his family in debt, both financially and socially. Judges in Court Y said it was common for those who have avoided jail time to take on a second

TABLE 2

Defendants Involved in Criminal Reconciliation at Court Y By EduCATion LeVEL, 2012-13

\begin{tabular}{|c|c|}
\hline Defendant's Education & $\%(\mathrm{n})$ \\
\hline University . & $4.4(9)$ \\
\hline High school. . & $16.7(34)$ \\
\hline Junior high . . & $47.8(97)$ \\
\hline Elementary . . . . . . . . . . . . . & $29.6(60)$ \\
\hline 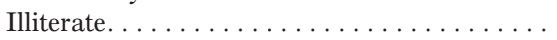 & $1.5(3)$ \\
\hline Total $\ldots \ldots \ldots \ldots \ldots \ldots \ldots \ldots$ & $100(203)$ \\
\hline
\end{tabular}


job to repay their debts. But for most defendants in China, this is still considered preferable to going to jail. As a judge explained to us,

With a growing economy today, most people can find a job to make a living. And if they work harder or get a second job, it is possible for a blue-collar worker to make 40,000 to 50,000 yuan a year. So a worker can make 100,000 yuan in two years [and live with his family to minimize expenses]. Of course, they have to give most of the money made to the other party. But for most Chinese families, this is considered a much better option, because the person still has his freedom if he's out. The person can still stay with his family members.

The third type of blood money hurts the most. It is money from home equity. Like many families in the United States, only to a greater extent, owning a property is a milestone for many Chinese families. The urban homeownership rate is $87 \%$ in China, a level that is 30 percentage points higher than in the United States; rural home ownership is an even higher $97 \%$ (Troutman 2014). For defendants who own a house, using its equity as blood money is a last resort. Precisely because it hurts so much, this type of blood money "buys" more sympathy from the party compensated. A judge in Court Y explained, "The other party knows that the defendant has no money left, otherwise he (defendant) wouldn't choose to sell his flat. In some cases, the victims' family was willing to wait because they knew it took time to sell a property. People usually understand." The type that draws the most sympathy from judges and opposing parties, the type of money that draws the most blood, so to speak, is the home equity of aging parents who are forced to sell their flats to raise money for their children. The taking of this kind of money hurts so much that even bereaved parents or children have sympathy for the other party, at least when there are no elements of malice or intentional harm. Another judge in Court Y recalled a case where an aged mother traveled from a remote province to save her child:

The victim was killed in the accident but the defendant had no money to compensate the victim's family. His elderly mother took the train all the way from Hubei [a province far from County Y] alone. She presented to us about 60,000 yuan and she told the victim's family that was all she got from selling her own flat. She lamented about her poor life and what it meant to have the son stay with her. And even though the victim's family was asking for more initially, they accepted the money and said they understood and forgave. They saw the old woman and knew it was very hard to be in the old woman's position. They sympathized.

Here we see the social value of the blood money offered by the aging mother of the defendant as something larger than its face value. In every society certain acts convey powerful symbolic messages. In China, even today, no images are more poignant and touching than an aging mother fighting and sac- 
rificing for her child. The blood nature of the money signaled how desperate the mother was to save her son from jail.

\section{Recipients}

The other dimension of the social nexus that affects value is the social position of the recipient. What litigants make of the offering of blood money varies. Blood money means more to poor recipients, but less to affluent ones. It is difficult to strike a deal with rich victims, most of whom want to send defendants to jail. They also seem to discount the value of the hardship in raising blood money. To use an economic metaphor, the marginal utility of more (blood) money declines when victims are wealthy. Conversely, poor victims seem to value the hardship factor more, above and beyond the fact that they need the money. Blood money has more impact on poor recipients in deciding whether they are willing to forgive.

When the recipients are courts rather than individuals, the impact of blood money depends on whether or not the courts need the money to cover their expenses. Chinese law empowers the courts to impose criminal fines for certain types of crimes, in particular, economic crimes such as smuggling, commercial fraud, speculation, counterfeits, and misappropriation of state funds (Art. 116-130 of Criminal Procedure Law). The money raised by defendants to pay as fines to the courts can also be regarded as a type of blood money. ${ }^{9}$ It is important to note that money paid to a court has different social meanings from that paid by a defendant to a victim. Courts in urban developed regions of China are comparatively well financed these days. Criminal fines are imposed not because these courts need the money but as an additional means of deterrence. As a result, they tend not to sentence more leniently just because a defendant agrees to pay the fine. A judge from Court Y said he told defendants who paid fines not to get their hopes up: "For us, paying fines helps only in the sense the defendant shows good attitude in admitting his crime. It is another way to show your remorse. But we are not the victim, we can't say: 'We forgive.'”

Another judge added, "In fact, they [fines] don't mean much to us. We don't put too much emphasis on defendants who volunteer to pay fines. The court is bound by the law. For some crimes, we impose fines. For others, we don't."

But for courts that are short on money, mostly those in inland provinces where the economy is less developed, the exchange between paying criminal fines and receiving less punishment is common. A judge must sentence

\footnotetext{
${ }^{9}$ By definition, criminal reconciliation refers only to the transaction between the two private parties, thus excluding the situation in which the courts reduce the penalty for criminal fines. We nonetheless regard criminal fines as a form of blood money because this inclusion helps us understand the relationship between money and justice in China's criminal justice system.
} 
within the range specified by the law. But judges in Court $\mathrm{X}$ acknowledged that they would sentence a defendant who paid a fine to the lower end of the range. One middle-aged judge said in an interview, "It was back to the early '90s when we found out that the criminal division could generate income. A tribunal in our county, for half a year, collected less than 100,000 yuan in litigation fees. But one criminal defendant was willing to pay this amount. When we came across a case like that, judges in the criminal division almost felt like celebrating." As documented by He (2009), cash-strapped courts in China asked their criminal division to meet a quota in generating income. The situation is different for courts such as Court Y, whose operational budget is not tied to their income. We asked the same judge in Court $\mathrm{X}$ about the situation of his court now.

"The district government never allocates more funds to us and we never hand in what we collected," the judge said. "The only difference is that back in the 1990s, the required annual quota for the criminal division was 20,000 yuan, but now it is one million yuan."

Other judges working in inland provinces also reported similar use of criminal fines as subsidies for their operational budgets. A judge who was the vice president of an intermediate court in Yunnan, a southwestern inland province bordering Myanmar, told us, "We differentiate defendants in terms of the fines we charge. For a poor farmer who is caught for drug trafficking, we might ask for no more than 100,000 yuan, for this might be all he could pay. For an official who is involved in economic crimes, we will ask for one million yuan or more, especially if his lawyer takes the initiative in approaching us." It seems that in order to maximize their income, these courts adopt a strategy akin to what economists describe as price discrimination. In other words, they expect the defendants to pay according to the best of their abilities.

We asked if judges always imposed a lighter sentence when a defendant agreed to pay criminal fines. "Yes we do," replied the same judge from Court X. "The sentencing ranges for both drug-related crimes and economic crimes are large and flexible. We can reduce a 20-year sentence to 15 or shorter. We do keep our promises.”

\section{Money Deflated and Inflated}

Despite its prevalence, criminal reconciliation, more precisely, the exercise of legal commensuration that makes reconciliation possible, remains controversial. Some litigants refuse to play the game because they value other things more. Others play the negotiation game defiantly in order to lose. These litigants either price off the social value of blood money or they price themselves out of the blood money market. In these cases, blood money operates in either a deflated or inflated moral economy. 
The value of blood money is at times deflated, denied, or discounted because of the value choices defendants made, the circumstances they face, or the beliefs they hold. Some litigants simply refuse to negotiate because they see the social purpose that blood money serves as less important, hence the devaluation of the moral worth of blood money. They would rather go to jail than give up their own money and ask their families to help raise money. Some migrant workers, for example, afraid of losing face and not wanting to "waste" family money, asked courts not to contact their families. A judge said, "It's our usual practice to ask defendants if they want to contact their families. But some refused to tell us their family contacts. They were usually migrant workers who had no local family ties. They didn't want their family to know. They didn't want their family to worry about them. They are determined not to put 'their family through hell.' " They are, in the eyes of judges, "hopeless" litigants for possible reconciliation because they do not fear imprisonment and are unwilling to work with the court. Relegated to the bottom of Chinese society (Solinger 1999), migrant workers have a specific understanding of blood money. They have a sense of responsibility to, and often pride in, their family members. As documented, they would choose not to visit their families during the Spring Festival, the biggest holiday of the year for the Chinese, if they could not bring some money home (He, Wang, and Su 2013). They seemed to think that if they had asked family members to pay, they would have lost not just the money, but also face. "They just told us, 'Why don't you sentence me to jail?'” said one judge in Court Y, which deals with a significant number of migrant workers each year. It is interesting to note that the very value that prompts some victims' families to take less money (because it is from the family) also in some cases deters defendants from raising blood money for their freedom. For this small group of defendants, it is a conscious choice of placing familial welfare over freedom.

Other litigants think of blood money as a poor substitute for blood. In such cases, blood money is forced to operate in a morally inflated moral economy, and its face value is deeply discounted. Some wealthy victims and their families value vindication and retribution more than monetary compensation and thus have a reputation among judges as difficult parties to reconcile. A different judge in Court Y said, "Sometimes reconciliation is impossible even if the defendant is willing because the victim asks for the moon. In one case, the family of a dead victim demanded one million yuan for compensation. Basically, the victim's family demanded far more than what they would have been awarded in civil litigation." The judge added, "With wealthy victims, they don't really need more money. An exorbitant demand for blood money is not a serious demand. Making an unreasonable demand is their way of turning down reconciliation and telling a defendant to go to jail." 
The families of some victims take pains to make it clear that they do not want any compensation. They want vindication. The Supreme People's Court judge from the Death Penalty Confirmation Division shared her story:

You cannot imagine the pressure we experienced. I was asked to talk to a victim's family who lost their only son to murder. The defendant's family hoped their son could be spared from death penalty. The victim's family flatly said no. But our division head would not approve the execution decision. So I was asked to negotiate with the victim's family many times. Eventually the family got annoyed. The mother said, "If you judges believe one can simply reconcile in such cases, what if I kill your son and pay you some money in return?"

Blood money is inflated in these scenarios - it buys even less than what its face value would have bought in normal circumstances because the other side has raised the asking price. It is also inflated because victims and their families do not take the hardship of collecting blood money into consideration to offer the defendant, as it were, a "moral discount." In cases where victims and their families refuse to negotiate, they demand a prohibitive price. Asking for the moon is a defiant way of doing what the court has asked one to do (meaning, "I still did what you asked me to do and negotiated with the other party, it's just that the other party could not fulfill my demand").

There is also the question of whether wealthy defendants might be asked to pay more in order to obtain forgiveness, since the money they pay in reconciliation does not hurt them as much and is therefore symbolically inflated. Our data do not offer a clear answer. As mentioned, well-educated and wealthy defendants were a small minority in the courts we studied. Some Chinese scholars (Xiao and Wang 2010) observed that there were more cases in which defendants compensated above the statutory standard, although it was unclear if this was a prevailing trend. We suspect that judges would closely scrutinize this phenomenon of overly high compensation. Judges, while eager to facilitate reconciliation, are wary of one party squeezing the most money from the other party and turning the procedure into a sheer exchange of money for punishment. In addition, based on what we saw in the courts we studied, it is not easy for the other party to tell if a defendant is wealthy or not. Judges are in a better position to know, but for many reasons (including not wanting to make the negotiation more difficult than it already is) they are not motivated to pass on the information to victims.

\section{INSTITUTIONAL AND CULTURAL LOGICS OF LEGAL COMMENSURATION}

In this study of criminal reconciliation, we show how Chinese judges broker deals with defendants and victims to pay blood money. Defendants receive reduced sentences while victims get the compensation they would not have 
received in civil litigations. Judges actively negotiate these sometimes arduous deals that take into consideration the crime and the injury inflicted as well as the social characteristics of defendants and plaintiffs. Along the way, the judges spend much time urging defendants to express contrition and offer apologies, admonishing some while empathizing with others, in their attempts to facilitate the offer and acceptance of blood money.

Like other institutionalized forms of commensuration, valuing life and life experiences in law is a complex exercise. Something that cannot be measured in money is "lost," and law compensates by putting a monetary value on that lost quality (Atiyah 1997; Cane 2013). But our study shows that there is a unique layer of complexity in legal commensuration-its relational quality. Legal commensuration in action is accomplished in the form of a payment from one party to another, from the party "at fault" to the claimant, or in our present Chinese case, from the convict to the victim. This harkens back to Simmel's idea about money that we discussed earlierthe payment, or more precisely, monetary exchange, is a form of sociation between the payer and the payee. ${ }^{10}$

In the case of the United States, this social quality is normally masked by the availability of institutional money such as workers' compensation, underinsured automobile insurance, and first- and third-party insurances. And as a result of the prevalence of vicarious liability, a great deal of the claims in the United States are made toward large corporations or public authorities, who act effectively as self-insurers, on top of their role as tortfeasors. In all these cases, the payer usually is a legal person rather than a natural person.

The case of China, as exotic as it may sound, is arguably a more straightforward case for studying the social character of legal commensuration. Criminal reconciliation arises as the insurance system in China is still very much under development. Rather than filing civil claims in conjunction with criminal trials, defendants and victims bargain with each other under the urging of the court. The bargaining is relatively free from the institutional trappings that conceal its nature as a form of social exchange. As we have shown, the meaning of blood money is constituted by what it means to the payer and to the payee.

Unlike their U.S. counterparts, Chinese judges are primarily evaluated by their abilities to preserve stability. They are sensitive to the potential adverse impacts of appeal and petition on their appraisals, and they have very limited institutional capital to expend on unpopular and controversial deci-

${ }^{10}$ Certainly, other results of commensuration, such as ranking and pricing systems, are complex. But their relations with the people and things ranked or priced are more indirect. Challenges to these mechanisms often come in at the metalevel, such as why certain criteria are adopted to commensurate comparisons. 
sions. They tend to be highly pragmatic (He and Ng 2013). Institutionally, criminal reconciliation proliferates as a risk-averting option. Judges want victims and families to accept court-brokered deals. They also push defendants to reconcile. Chinese judges' discourse of promoting criminal reconciliation values social harmony over principled reasoning - "If the victim's family doesn't change their attitude, it is likely that we'll have to levy a heavier punishment." This way of talking appears to be normal to frame reconciliation in China, given that maintaining social stability is considered an essential part of judges' official function. Indeed the self-evident nature, in the judges' eyes, of that social function comes through very powerfully in the interview material, so much so that judges are very open about exercising their discretionary power.

The courts we studied used different tactics and strategies to persuade victims and defendants to agree to reconciliation. The intensive all-out efforts observed in some cases are impossible to carry out as an ordinary mode of operation. As such, it is not a justice system based on rules but rather a form of negotiated justice that is motivated by the institutional incentives and disincentives to which judges are subjected. Judges so value the maintenance of social stability and avoidance of petitions that they allow some criminals to have their jail terms shortened or suspended. Indeed, the Chinese system is aggressive in the sense that the possible substitution of money for criminal sentences is adopted as a broad policy nowadays and has become an integral part of its criminal justice system. The rich, by reaching a reconciliatory arrangement with victims, can avoid jail, at least for minor criminal charges. Critics of criminal reconciliation are right in pointing out that undiscriminating use of the process would lead to greater inequalities between the rich and the poor (Li 2006; Ge 2010; Rosenzweig et al. 2012).

That said, one of the interesting aspects of the Chinese case is that the money is clearly not just there to simply offload responsibilities between strangers. The exchange of money signals the building (or repair) of social relations. Skeptics might say that our relational account of legal commensuration works only in China because of the highly negotiated nature of this process. That money is given this role in part reflects the weak institutional authority of the judiciary in which judges operate. Can the same be said about the social and relational quality of legal commensuration in the more institutionalized legal system of the United States? Certainly, the role of money in the criminal justice system of the United States is different. In the judicial system of the United States, monetary or economic sanctions are also a common means of punishment among probationers and even inmates (Durose and Langan 2003; Harris, Evans, and Beckett 2010). Among different forms of economic sanctions, money paid by felony offenders to compensate victims, or restitution money, resembles most closely the Chinese case of blood money. Restitution is institutionalized through four dif- 
ferent judicial programs or procedures (Ruback and Bergstrom 2006): (a) as a component of victim/witness assistance programs, (b) through victimoffender reconciliation programs, (c) in conjunction with probation or parole supervision, and (d) through court-based employment programs. As a more institutionalized form of "payback," open negotiations in the Chinese style do not seem to be prevalent. But U.S. judges are known to be reluctant to impose restitution on offenders who are believed to be unable to pay. In contrast, they are more likely to order restitution when the offender is better educated and employed (Lurigio and Davis 1990).

More important for our purpose, the merits and demerits of restitution and other forms of economic sanction are primarily considered in the context of an expansive penal system in the United States. Economic sanction is viewed by some as an effective alternative to reduce recidivism (Outlaw and Ruback 1999), while others warn that the legal debts that result from economic sanctions perpetuate the accumulation of disadvantage over the life course of a convict (Harris et al. 2010). In other words, the institutional logic that prompts U.S. judges to impose restitution money is different from that identified in the Chinese case. Restitution money is neither perceived nor used in the United States as a means to shore up litigants' support for court decisions. Restitution money is paid after sentencing. ${ }^{11}$ In contrast, Chinese judges usually ask offenders to pay blood money before sentencing, because they want to secure the support of victims. The constant concern of Chinese judges with their fragile institutional authority does not seem to loom large as an institutional incentive for promoting criminal reconciliation in the United States. Judges in the United States are less worried about appeals than about their perceived independence and impartiality (Tyler 1990).

The process of reconciliation is also more depersonalized in the United States. For example, that a defendant showed remorse or was contrite in court certainly constitutes a common mitigating circumstance. Yet such factors are formally considered in the context of a criminal bench trial or sentencing hearing (Strang and Sherman 2003; Rachlinski, Guthrie, and Wistrich 2013). ${ }^{12}$ As legal scholars point out, remorse and apology "often lurk in the interstices, appearing only as pro forma statements from defendants to judges at sentencing" (Bibas and Bierschbach 2004, p. 92). In short, the mechanism of commensuration is so embedded in a legal-technical discourse that it has sundered the social and relational quality that we identify in the Chinese case. Yet we would argue that although payers and payees do

\footnotetext{
${ }^{11}$ The collection rates of restitution in the United States are low (see National Center for Victims of Crime 2011).

${ }^{12}$ For a historical overview of the role of repentance in the criminal justice system and its relationship to modern theories of punishment, see Wuthnow (1997).
} 
not negotiate with each other as natural persons (parties are often not real persons), the social and relational aspect of legal commensuration is not erased but only routinized. As Baker's (2001) study of tort compensation reveals, that relational and meaning-making aspect reemerges when, for example, a litigant decides to game the system or when the defendant's conduct is so egregious that it goes beyond the scope of a simple mistake.

The adoption of a more analytical language to talk about legal commensuration in the United States does not seem to have resolved the inherent complexity of legal commensuration. The practice continues to defy standardization. Judges and scholars have been debating about principles for justly providing commensuration for a wide range of life experiences, including lost income, individuated damages, suffering and distress, loss of life's pleasure, loss of companionship, humiliation, and indignity suffered by defendants or heirs in the case of death or serious injury (Ogus 1972; Posner and Sunstein 2005; Cane 2013). The recent law and economics way to value things is to look for their values in a relationship of supply and demand, market value, that is. But there is no "market" for these intangibles. So in order to establish market values, economics-minded judges look for indications of how much value people put on their lives as such, what some would call the "hedonic" value of life (Viscusi 2000; Cane 2013). They try to get to hedonic value by looking at, for example, wage differentials between more or less risky jobs; the idea is that such differentials can work as serviceable proxies for calculating how much people are willing to pay to reduce the risk of death. But here this "willingness-to-pay" approach runs into the same problem that underlies the phenomenon of blood money, only from the opposite side of the mountain - money does not mean the same thing to everyone. Or in economic jargon, "the marginal utility of money" varies. ${ }^{13}$

Neither does the traditional "make-whole" approach fare better. The make-whole principle seeks to make the victim whole again by compensating for the value of the loss that has been incurred. But there is always a fictional quality to the claim that offering money to a victim who suffers permanent health impairments or even death makes the person whole again. Monetary compensation is supposed to return a victim to the status quo ante, but in many cases restitutio in integrum is impossible. The event (e.g., a traffic accident) that monetary compensation seeks to rectify often diminishes the marginal utility of money to that person. This goes back again to the question of the varying marginal utility of money, a question that lies at the heart of the debate over setting appropriate compensation (Viscusi 2000). From our

${ }^{13}$ To use a simple example, it is well documented that a wealthy person is more likely to pay for his safety than a poor person (Mrozek and Taylor 2002; Viscusi and Aldy 2003). 
perspective, this tail-chasing recursivity merely testifies to the endogenously social quality of legal commensuration.

The eminently social character of legal commensuration can only be fully appreciated when the meaning of blood money is interpreted through the broader cultural logic of a society, understood as forms of discourse and understanding that become elements of the principles of exchange (DiMaggio 2001, p. 231). Here we identify visible differences between the United States and China. Although promoted by the court, legal commensuration in China represents a partial devolution of power to litigating parties. Litigants imbue the negotiation process with a moralizing logic of valuation that goes against the quantitative calculus of commensuration. The process of reconciliation makes salient stories about how defendants raised the money and what the money meant to them. The cases we came across in China suggest that the cultural biography of blood money matters - as the case of aging mother who sold her house showed, the value of that blood money was greatly increased. In the United States, the families may not behave with such solidarity to help their members who are convicted of petty crimes. ${ }^{14}$ It seems that the Confucian "blood-is-thicker-than-water" doctrine of familial commitment makes a difference here.

In the United States, blood money facilitates one kind of reparation to a victim - making the defendant hurt more, in a way that insurance money cannot (Baker 2001). In contrast, blood money in China makes the defendant hurt less than the alternative of imprisonment. It also facilitates reparation to a victim, albeit of a different kind, through the act of apology and forgiveness. It is therefore understood that blood money does compensate in both systems but that it provides commensuration from different moral values in China and the United States. This most fascinating "localizing" adaptation shows, shall we say, the cunning of culture. The bringing in of cultural values not only disrupts the singular economistic rules that facilitate uniform conversion but also explains the plurality of practices in different cultural settings.

\section{Conclusions}

Our study of criminal reconciliation in China unveils the complexity of legal commensuration from a less familiar setting. A key to understanding its operations, we argue, is the institutional and cultural logics embedded in the practice. Indeed, as our brief comparison with the U.S. case shows, this

\footnotetext{
${ }^{14}$ Existing studies of restitution in the United States do not list family support as a major factor that enhances the likelihood of payment. Instead, offenders are more likely to pay if they are (a) told about the importance of restitution, (b) given employment opportunities, (c) closely supervised, and (d) allowed to pay in installments (Ruback and Bergstrom 2006, p. 252).
} 
approach sheds light beyond the case of China. Our study also echoes Zelizer's (1979, 1985, 1994) and Fourcade's (2011) works, which advocate for the centrality of cultural meaning in shaping seemingly economically driven practices of valuation and commensuration. Attention to institutional incentives and cultural values enables sociologists to distinguish types of institutional commensuration. For example, to attribute monetary compensations to death has been a task assigned to both regulating agencies and courts. But values are calculated differently by the two institutions. Public agencies tend to assign a uniform price to a death, while courts often award individualistic compensations (Posner and Sunstein 2005). In this case, the difference in institutional priorities explains why commensuration varies: public agencies focus on the ex ante effects compensations can bring, but courts' concern is mainly ex post. Public agencies derive their numbers from "scientific" cost-benefit analyses; judges and juries are faced with in-person litigants whose presence in the adversarial trial makes for a more personal encounter. Our processual focus shows that courts tend to attend to individualized facts and numbers in providing commensuration for emotions, experiences, and economic losses.

At the same time, variations in commensuration within the same institution over time can be accounted for by referring to changes in the wider cultural environment. As pointed out by Zelizer (1985), the price of children who died a wrongful death has been increased from little to virtually nothing in the 19th century to more than one million dollars by the end of the 20th century. This can be accounted for by the cultural change in the way children are valued. Fourcade (2011, p. 1734) notes that the courts in the United States have relied more on external expertise than on the common sense of juries and judges in the search for fair compensation, and she argues that this change stems from "the culture of "discovery'" (emphasis added). The explanatory power of institutional and cultural logics represents a step toward a more systematic and theoretical conception of legal commensuration.

Our analysis of blood money in China also contributes to the understanding of the social meanings of money. Numerous studies have pointed out that the social meanings of money vary with reference to its sources, its media of representation, and its recipients (Shipton 1989; Carruthers and Espeland 1991; Zelizer 1994; Heath and Soll 1996; Thaler 1999; Stinchcombe 2001). Our findings from China not only verify this point but also further expand on the Simmelian point that monetary exchange is a form of sociation. The social dynamic between the defendant and the victim matters. The value of money is sometimes deflated, sometimes inflated in relation to given social relations. Most important, it demonstrates a connection between the different types of (blood) money and social inequality in legal commensuration. Wealthy victims can simply ask for the moon for compen- 
sation in order to put offenders behind bars, but poor victims cannot afford the freedom to refuse money. Meanwhile, most defendants can avoid imprisonment by offering their own savings or enlisting the help of their families. But migrant defendants who do not even want their criminal predicament known to their families are literally and figuratively imprisoned. In negotiating compensation, social inequality is manifest by the disparate evaluations that the rich and the poor bestow on blood money. Our findings thus open a new set of research questions: What is the relationship between the disparate meanings of money and the reproduction of social inequality? How does the situation in the United States differ from that in China? For example, if, as Baker (2001) points out, blood money in the United States is an expression for personal revenge, will the effect of blood money remain the same when levied against tort litigants of lower social status and resources? Law and society scholars have long suggested that resource inequality affects case outcome (Galanter 1974; Wheeler et al. 1987; He and $\mathrm{Su} 2013$ ). How will the social meanings of money, once incorporated into the analysis, tip the scales of justice?

Finally, the significance of political consideration in our analysis suggests that criminal reconciliation is a phenomenon that has only become prevalent in this period in China. Negotiated justice stems from the limited ability of the court to adjudicate. The weak capabilities in enforcing civil judgments and a lack of social security net indicate that the state's power and resources are limited. To prevent petitions and protests that threaten social stability, courts are asked to pacify warring parties. As demonstrated, judges exhausted all possible means in order to get a reconciliation agreement done. Besides putting in extra efforts and time and offering tokens of sincerity, they even put in their own blood money. As a study of the Chinese criminal justice system, the role of blood money sensitizes us to take note of the limits of the penetration of state power in China today. Traditionally, scholarship on the Chinese legal system has focused on its repressive and authoritarian character (Cohen 1968, 2011; Trevaskes 2007a, 2007 b; McConville et al. 2011; McConville and Pils 2013). While the state machinery remains selectively repressive, scholarship since the mid-2000s has begun to pay more attention to the significant move from repression to a more lenient regime (Liebman 2012; Trevaskes 2009, 2010). Our study echoes this literature by revealing its weak and malleable side: its capability to adjudicate is rather limited as it is often forced to negotiate with private litigants in order to get cases resolved. Our study thus paints a more complicated and evolving picture of negotiated justice, in which the social meanings of money, the political concerns of the courts, economic benefits, and sense of justice are all in play. These findings not only uncover the dynamics of criminal law practice but also reveal the complicated relationship among law, politics, money, and perceptions of justice. 
For the system to work, much, perhaps too much, discretionary power is given to judges, creating a system that is structurally susceptible to abuse. Judges are in a position to broker deals by applying pressure on litigants - a power that is desirable to some litigants and one that may command its own price. The discretionary power that Chinese judges hold means that corruption is a concern, particularly with judges working in the poorer inland regions of the country whose salaries are known to be well below their colleagues working in the cities.

\section{REFERENCES}

Abel, Richard. 1990. "A Critique of Torts." UCLA Law Review 37:785-831.

Ackerman, Frank, and Lisa Heinzerling. 2002. "Pricing the Priceless: Cost-Benefit Analysis of Environmental Protection." University of Pennsylvania Law Review 150 (5): 1553-84.

- 2004. Priceless: Human Health, the Environment, and the Limits of the Market. New York: New Press.

Anderson, Margo. 1990. The American Census: A Social History. New Haven, Conn.: Yale University Press.

Anderson, Terry, and Donald Leal. (1991) 2001. Free Market Environmentalism, rev. ed. New York: Palgrave Macmillan.

Atiyah, P. S. 1997. The Damages Lottery. Oxford: Hart Publishing.

Baker, Tom. 2001. "Blood Money, New Money and the Moral Economy of Tort Law in Action." Law and Societv Review 35:275-319.

Balme, Stephanie. 2010. "Local Courts in Western China: The Quest for Independence and Dignity. Pp. 154-79 in Judicial Independence in China: Lessons for Global Rule of Law Promotion, edited by Randall Peerenboom. New York: Cambridge University Press.

Bell, Peter A., and Jeffrey O' Connell. 1997. Accidental Justice. New Haven, Conn.: Yale University Press.

Bibas, Stephanos, and Richard A. Bierschbach. 2004. "Integrating Remorse and Apology into Criminal Procedure." Yale Law Journal 114:85-148.

Cane, Peter. 2013. Atiyah's Accidents, Compensation and the Law. 8th ed. New York: Cambridge University Press.

Carruthers, Bruce G. 2010. "The Meanings of Money: A Sociological Perspective." Theoretical Inquiries in Law 11:51-74.

Carruthers, Bruce G., and Wendy N. Espeland. 1991. "Accounting for Rationality: Double-Entry Bookkeeping and the Rhetoric of Economic Rationality.” American Journal of Sociology 97:31-69.

Chen, Xiaomin (陈晓明). 2011. The Fundamental Theory of the Victim-Offender Mediation on Criminal Matters (in Chinese) (刑事和解原论). Beijing: Legal Press.

Cheng, Jianjun (程建军). 2012. “Civil Mediation in Criminal Reconciliation” (刑事和解视 野下的附带民事调解). http://www.fk.gov.cn/10171/10171/10000/2012/122605.htm. Accessed November 4, 2013.

Clarke, Donald. 1996. "Power and Politics in the Chinese Court System: The Execution of Civil Judgments." Columbia Journal of Asian Law 10 (1): 1-125.

Cohen, Jerome A. 1968. The Criminal Process in the People's Republic of China, 19491963. Cambridge, Mass.: Harvard University Press.

—. 2011. "Turning a Deaf Ear." South China Morning Post. June 9, 2011.

Cohen, Patricia Cline. 1984. A Calculating People: The Spread of Numeracy in Early America. Chicago: University of Chicago Press. 


\section{American Journal of Sociology}

CPL (Criminal Procedure Law). 2012. Amended on March 17, 2012. National People's Congress of the People's Republic of China.

DiMaggio, Paul. 2001. "Conclusion." Pp. 210-43 in The Twenty-First-Century Firm, edited by Paul DiMaggio. Princeton, N.J.: Princeton University Press.

Durkheim, Émile. (1898) 2013. "Individualism and the Intellectuals." Pp. 150-63 in Durkheim and the Law, 2d ed. Edited by Steven Lukes and Andrew Scull. New York: Palgrave.

Durose, Mathew R., and Patrick A. Langan. 2003. "Felony Sentences in State Courts, 2000.” BJS Bulletin NCJ 198821. Washington, D.C.: U.S. Department of Justice. http://www.bjs.gov/content/pub/pdf/fssc00.pdf. Accessed December 10, 2014.

Easton, David. 1965. A Systems Analysis of Political Life. New York: John Wiley \& Son.

Edelman, Lauren B. 1992. "Legal Ambiguity and Symbolic Structures: Organizational Mediation of Law." American Journal of Sociology 97:1531-76.

Espeland, Wendy N., and Michael Sauder. 2007. "Rankings and Reactivity: How Public Measures Recreate Social Worlds." American Journal of Sociology 113:1-40.

Espeland, Wendy N., and Mitchell L. Stevens. 1998. "Commensuration as a Social Process." Annual Review of Sociologv 24:313-43.

Espeland, Wendy N., and Berit I. Vannebo. 2007. "Accountability, Quantification, and Law." Annual Review of Law and Social Science 3:21-43.

Fourcade, Marion. 2011. "Cents and Sensibility: Economic Values and the Nature of 'Nature."' American Journal of Sociology 116:1721-77.

Galanter, Marc.1974. "Why the 'Haves' Come Out Ahead: Speculations on the Limits of Legal Change." Law and Societv Review 9:95-160.

Ge, Lin (葛琳). 2008. Research on Criminal Reconciliation (刑事和解研究). Beijing: University of Police Press

. 2010. "An Analysis on the Practical Predicament of Criminal Reconciliation" (刑事和解的现实困境解析). Justice of China (中国司法) 5:19-22.

Gerriets, Marilyn. 1985. "Money in Early Christian Ireland According to the Irish Laws." Comparative Studies on Societv and Historv 27:323-39.

Harris, Alexes, Heather Evans, and Katherine Beckett. 2010. "Drawing Blood from Stones: Legal Debt and Social Inequality in the Contemporary United States." American Journal of Sociology 115:1753-99.

He, Xin. 2009. "Court Finance and Court Reactions to Judicial Reforms: A Tale of Two Chinese Courts." Law and Policy 31 (4): 463-86.

He, Xin, and Kwai Ng. 2013. "Pragmatic Discourse and Gender Inequality in China." Law and Societv Review 47 (2): 279-310.

He, Xin, and Yang Su. 2013. "Do the 'Haves' Come Out Ahead in Shanghai Courts?" Journal of Empirical Legal Studies 10 (1): 121-46.

He, Xin, Lungang Wang, and Yang Su. 2013. "Above the Roof, Beneath the Law: Perceived Justice among Migrant Wage Claimants in China." Law and Societv Review 47 (4): 703-37.

Heath, Chip, and Jack Soll. 1996. "Mental Budgeting and Consumer Decisions." of Consumer Research 23:40-52.

Huang Jingping (黃京平). 2013. "From Policy to Law: the Operation of Criminal Reconciliation” (刑事和解的政策性运行到法制化运行). China Legal Science (中国法学) 3:16379.

Ingham, Geoffrey. 2004. The Nature of Money. Cambridge: Polity Press.

Karpik, Lucien. 2010. Valuing the Unique: The Economics of Singularities. Princeton, N.J.: Princeton University Press.

Lampton, David M. 1992. "A Plum for a Peach: Bargaining, Interest, and Bureaucratic Politics in China." Pp. 33-45 in Bureaucracy, Politics, and Decision Making in PostMao China, edited by Kenneth Lieberthal and David M. Lampton. Berkeley: University of California Press. 
Levin, Peter, and Espeland, Wendy N. 2002. "Pollution Futures: Commensuration Commodification and the Market for Air." Pp. 119-47 in Organizations, Policy, and the Natural Environment, edited by A. J. Hoffman and M. J. Ventresca. Stanford, Calif.: Stanford University Press.

Li, Hongjiang (李洪江). 2006. “The Implementation of Criminal Reconciliation Should Be Slowed Down” (刑事和解应缓行). The Chinese Procurators (中國檢察官) 5:13-14.

Liebman, Benjamin. 2012."Professionals and Populists: The Paradoxes of China's Legal Reforms." Pp. 214-30 in China beyond the Headlines, 3d ed. Edited by Timothy Weston and Lionel Jensen. London: Rowman \& Littlefield.

Lurigio, Arthur J., and Robert Carl Davis. 1990. "Does a Threatening Letter Increase Compliance with Restitution Orders? A Field Experiment." Crime and Delinquency 36:537-48.

Lutter, Randell. 2000. "Valuing Children's Health: A Reassessment of the Benefits of Lower Lead Levels.” Working Paper No. 00-2. AEI-Brookings Joint Center for Regulatory Studies.

McConville, Mike, Satnam Choongh, Pinky Choi Dick Wan, Eric Chui Wing Hong, Ian Dobinson, and Carol Jones. 2011. Criminal Justice in China: An Empirical Inquiry. Northampton, Mass.: Edward Elgar.

McConville, Mike, and Eva Pils, eds. 2013. Comparative Perspectives on Criminal Justice in China. Northampton, Mass.: Edward Elgar.

Minzner, Carl F. 2009. "Judicial Disciplinary Systems for Incorrectly Decided Cases." New Mexico Law Review 39:63-87.

Mok, Louis W. Y., and Dennis S. W. Wong. 2013. "Restorative Justice and Mediation: Diverged or Converged?" Asian Journal of Criminology 8:335-47.

Mrozek, J. R., and L. O. Taylor. 2002. "What Determines the Value of Life? A MetaAnalysis." Journal of Policy Analysis and Management 21 (2): 253-70.

National Bureau of Statistics in China. 2013. China Statistical Yearbook 2013.

National Center for Victims of Crime. 2011. "Making Restitution Real: Five Case Studies on Improving Restitution Collection.” http://www.victimsofcrime.org/docs/Reports\%20 and\%20Studies/2011_restitutionreport_web.pdf?sfvrsn=2. Accessed December 12, 2014.

$\mathrm{Ng}$, Kwai Hang, and Xin He. 2014. "Internal Contradictions of Judicial Mediation in China." Law and Social Inquiry 39 (2): 285-312.

Ogus, A. I. 1972. "Damages for Loss Amenities: For a Foot, a Feeling, or a Function?" Modern Law Review 35 (1): 1-17.

Outlaw, M. C., and R. B. Ruback. 1999. "Predictors and Outcomes of Victim Restitution Orders.” Justice Quarterly 16:847-69.

Porter, Theodore. 1995. Trust in Numbers: The Pursuit of Objectivity in Science and Public Life. Princeton, N.J.: Princeton University Press.

Posner, Eric A., and Cass R. Sunstein. 2005. "Dollars and Death." University of Chicago Law Review 72:537-98.

Posner, Richard. 2008. How Judges Think. Cambridge, Mass.: Harvard University Press.

Rachlinski, Jeffrey J., Chris Guthrie, and Andrew J. Wistrich. 2013. "Contrition in the Courtroom: Do Apologies Affect Adjudication?" Cornell Law Review 98:1189-1244.

Rosenzweig, Joshua, Flora Sapio, Jiang Jue, Teng Biao, and Eva Pils. 2012. "Comments on the 2012 Revision of the Chinese Criminal Procedure Law." Pp. 455-503 in Comparative Perspectives on Criminal Justice in China, edited by Mike McConville and Eva Pils. Cheltenham: Edward Elgar.

Ruback, R. Barry, and Mark Bergstrom. 2006. "Economic Sanctions in Criminal Justice: Purposes, Effects, and Implications." Criminal Justice and Behavior 33 (2): 242-73.

Sha, Qironggui (萨其荣桂). 2012. “The Actors of Criminal Reconciliation” (刑事和解实践 中的行动者). Modern Legal Science (现代法学) 34 (2): 97-114.

Shipton, Parker. 1989. Bitter Money: Cultural Economy and Some African Meanings of Forbidden Commodities. Washington, D.C.: American Anthropological Association. Simmel, Georg. (1907) 1990. The Philosophy of Money. New York: Routledge. 


\section{American Journal of Sociology}

Solinger, Dorothy. 1999. Contesting Citizenship. Berkeley: California University Press. Song, Yinghui (宋英辉). 2008. “Empirical Analysis on Criminal Reconciliation” (我国刑事 和解的实证分析). China Legal Science (中国法学) 5:123-35.

— 2009. "Empirical Studies on Criminal Mediation in Public-Prosecuted Cases" (公诉案件刑事和解的实证研究). Chinese Journal of Law (法学研究) 3:3-22.

- ed. 2011. A Study on Criminal Reconciliation (刑事和解制度研). Beijing: Peking University Press.

Stinchcombe, Arthur. 2001. When Formality Works: Authority and Abstraction in Law and Organizations. Chicago: Chicago University Press.

Strang, Heather, and Lawrence W. Sherman. 2003. "Repairing the Harm: Victims and Restorative Justice." Utah Law Review 2003:15-42.

Stryker, Robin. 1990. "A Tale of Two Agencies: Class, Political-Institutional, and Organizational Factors Affecting State Reliance on Social Science." Politics and Societv 18 (1): $101-41$.

$\mathrm{Su}, \mathrm{Li}$ (苏力). 2000. Bring the Law to the Countryside (送法下乡). Beijing: China's University of Political Sciences and Law Press.

Sun, Qing (孙勤). 2011. An Analysis on the Value of Criminal Reconciliation (刑事和解价 值分析). Beijing: Chinese University of Police Press.

Sunstein, Cass, Daniel Kahneman, and David Schkade. 2000. "Assessing Punitive Damages.” Pp. 232-58 in Behavioral Law and Economics, edited by Cass Sunstein. New York: Cambridge University Press.

Thaler, Richard. 1999. "Mental Accounting Matters." Journal of Behavior Decision Making 12 (3): 183-206.

Trevaskes, Susan. 2007a. Courts and Criminal Justice in Contemporary China. Lanham, Md.: Lexington Press.

. 2007b. "Severe and Swift Justice in China." British Journal of Criminology 47 (1): 23-41.

. 2009. "Restorative Justice or McJustice with Chinese Characteristics" Pp. 77-96 in Twenty-first Century China: Views from Australia, edited by Mary Farquhar. Cambridge: Cambridge Scholars Publishing.

. 2010. "The Shifting Sands of Punishment in China in the Era of 'Harmonious Society.'" Law and Policy 32 (3): 332-61.

Troutman, Kent. 2014. "Headwinds to Further Residential Investment." http://blogs .piie.com/china/?p=4085. Accessed December 7, 2014.

Tyler, Tom. 1990. Why People Obey the Law. New Haven, Conn.: Yale University Press.

Upham, Frank K. 2005. "Who Will Find the Defendant If He Stays with His Ship? Justice in Rural China." Yale Law Journal 114:1675-718.

Vidmar, Neil, and Matthew Wolfe. 2009. "Punitive Damages." Annual Review of Law and Social Science 5:179-99.

Viscusi, W. Kip. 2000. "The Value of Life in Legal Contexts." American Law and Economics Review 2 (1): 195-222.

Viscusi, W. Kip, and Joseph Aldy. 2003. "The Value of a Statistical Life: A Critical Review of Market Estimates Throughout the World." Journal of Risk and Uncertainty 27 (1): $5-76$.

Waye, Vicki, and Ping Xiong. 2011. The Relationship between Mediation and Judicial Proceedings in China. Asian Journal of Comparative Law 6 (1): 29-60.

Wheeler, Stanton, Bliss Cartwright, Robert A. Kagan, and Lawrence M. Friedman. 1987. "Do the Haves Come Out Ahead? Winning and Losing in State Supreme Courts, 1870-1970." Law and Society Review 21 (3): 403-45.

Wuthnow, Robert. 1997. "Repentance in Criminal Procedure: The Ritual Affirmation of Community." Pp. 171-90 in Repentance: Comparative Perspective, edited by Amitai Etzioni and David E. Carney. Lanham, Md.: Rowman \& Littlefield.

Xiang, Yan. 2013. "Criminal Mediation in Mainland China." Asian Journal of Criminology 8:247-56. 
Xiao, Yangqi (肖延齐) and Qingdong Wang (王庆东). 2010. “Judicial Control of High Compensation in Criminal Reconciliation of Minor Injury Cases” (轻伤害刑事和解案 件高额赔偿现象的司法控制). Chinese Procurators 10: 16-8.

Zelizer, Viviana A. 1979. Morals and Markets: The Development of Life Insurance in the United States. New York: Columbia University Press.

1985. Pricing the Priceless Child: The Changing Social Value of Children. New York: Basic Books.

1994. The Social Meaning of Money. New York: Basic Books.

2005. The Purchase of Intimacy. Princeton, N.J.: Princeton University Press.

Zheng, Li. 2012. "Revival and Development of the Criminal Reconciliation System in China." Social Sciences in China 33 (4): 168-78

Zhu, Jingwen (朱景文). 2011. Report on China Law Development 2011 (中国法律发展报告). Beijing Remin University of China. 